\title{
Komunikasi Profetik dalam Mengajak Santri Non Mukim Menghafal al-Qur'an (Studi Kasus di Pondok Pesantren al-Ittifaqiah Indralaya Ogan Ilir Sumatera Selatan)
}

\author{
Yenrizal, Reza Aprianti, Zulva hurin'in \\ Fakultas Ilmu Sosial dan Ilmu Politik Universitas Islam Negeri Raden Fatah Palembang \\ Email: zulvah144@gmail.com
}

\begin{abstract}
Communication is very important role for human life in socializing even in the teaching and learning process. This study describes prophetic communication in Islamic boarding school which aims to understand the process of prophetic communication in inviting non-resident Islamic Boarding School students to memorize the Qur'an. This study presents two substance problems, namely: 1) How does the implementation of prophetic communication in inviting non-resident students to memorize Al-Qur'an at Al-Ittifaqiah Islamic Boarding School ?. 2) What are the obstacles encountered when inviting non-resident students to memorize the Qur'an? To obtain answers to the problems above, this study uses descriptive qualitative research methods of analysis that is grouping data according to their categories and outlining all concepts related to the research discussion. The data sources of this study are non-resident students and tahfizh teachers of AlIttifaqiah Islamic Boarding School. Furthermore, data collection methods used are through observation, interviews, and documentation. The data obtained will be analyzed using data reduction, data presentation, and drawing conclusions. This research uses the theory of message reinforcement (reinforcement theory). The results of this study indicate that prophetic communication conducted by Al-Ittifaqiah Islamic Boarding School, namely the teachers communicate well (ma'ruf) to their students, so that it has a good effect on the students. Then provide motivation that can increase the spirit of memorizing the students. Socialization was also held by Islamic boarding schools by giving awards to high-achieving students. While the inhibiting factor in inviting non-resident students to memorize the Qur'an is, it is difficult to communicate directly with students because of the influence of distance. Then the residential environment that does not support where non-resident students do not live in boarding school resulting negligence in memorizing and inhibiting the process of memorizing students.
\end{abstract}

Keywords: communication, prophetic, memorize, islamic boarding school al-ittifaqiah. 


\begin{abstract}
Abstrak
Komunikasi memiliki peran yang sangat penting bagi kehidupan manusia. Baik dalam bersosialisasi maupun pada saat proses belajar mengajar. Penelitian ini menggambarkan komunikasi profetik di pondok pesantren yang bertujuan untuk memahami proses komunikasi profetik dalam mengajak santri non mukim menghafal Al-Qur'an. Penelitian ini menyajikan dua subtansi permasalahan yaitu: 1) Bagaimana pelaksanaan komunikasi profetik dalam mengajak santri non mukim menghafal Al-Qur'an di Pondok Pesantren Al-Ittifaqiah?. 2) Apa saja hambatan yang didapatkan saat mengajak santri non mukim menghafal Al-Qur'an?. Permasalahan di atas akan dijawab dengan menggunakan metode penelitian kualitatif yang bersifat deskriptif analisis yaitu mengelompokkan data sesuai dengan kategorinya serta menguraikan seluruh konsep yang berkaitan dengan pembahasan penelitian. Sumber data penelitian ini adalah santri non mukim serta guru tahfizh Pondok Pesantren Al-Ittifaqiah. Selanjutnya, metode pengumpulan data yang digunakan adalah melalui observasi, wawancara, dan dokumentasi. Data yang diperoleh akan dianalisis meggunakan reduksi data, penyajian data, dan penarikan kesimpulan. Penelitian ini menggunakan teori penguatan pesan (reinforcement theory). Hasil dari penelitian ini menunjukkan bahwa komunikasi profetik yang dilakukan Pondok Pesantren Al-Ittifaqiah yakni para guru berkomunikasi dengan baik ( $m a$ 'ruf) kepada santrinya sehingga menimbulkan efek baik bagi para santri. Kemudian memberikan motivasi yang dapat meningkatkan semangat menghafal para santri. Sosialisasi juga diadakan oleh pondok pesantren dengan memberikan penghargaan bagi santrisantri yang berprestasi. Sedangkan faktor penghambat dalam mengajak santri non mukim untuk menghafal Al-Qur'an yaitu, sulitnya berkomunikasi langsung dengan para santri karena pengaruh jarak. Kemudian lingkungan tempat tinggal yang tidak mendukung dimana santri non mukim tidak bertempat tinggal di pondok pesantren sehingga menimbulkan kelalaian dalam menyetorkan hafalan serta menghambat proses menghafal santri.
\end{abstract}

Kata kunci : komunikasi, profetik, menghafal, pesantren, al-ittifaqiah.

\title{
PENDAHULUAN
}

Mempelajari komunikasi adalah mempelajari proses sosial yang aktual, dimana bentuk simbol yang signifikan diciptakan, muncul, dan digunakan. Komunikasi bertujuan untuk mengkontruksi, memelihara, memperbaiki dan mentransformasi realitas. Istilah komunikasi digunakan dalam arti yang sangat luas untuk menampung semua prosedur yang bisa digunakan oleh satu pikiran untuk mempengaruhi pikiran lain. Karena itu hampir seluruh proses komunikasi adalah persuasi. Persuasi dapat diartikan sebagai perubahan sikap seseorang akibat paparan informasi dari orang lain. Perubahan sikap tersebut termasuk dalam keyakinan yang dianut sebelumnya.

Secara historis, komunikasi merupakan instrument yang integral dari Islam sejak kelahiran Islam sebagai gerakan religious-politis. Selama berabad-abad, budaya dan peradaban Islam, bahkan produksi teks suci (Al-Qur'an) dipengaruhi oleh pola komunikasi budaya setempat. Seni 
budaya dan komunikasi lisan dalam masyarakat Islam menemukan ungkapan terbaiknya dalam AlQur'an, sunnah Rasul, dan hadist. Al-Qur'an merupakan sumber utama untuk menjelaskan praktik dan aturan (teorisasi) komunikasi.

Namun sangat disayangkan karena banyak sekali perkembangan sejarah komunikasi yang diterbitkan menurut perspektif Barat sehingga dengan mudah melupakan bahwa sejarah Islam memberi kontribusi yang cukup besar bagi perjalanan sejarah komunikasi manusia (Syahputra, 2007). Masih banyak fakta sejarah mengenai kontribusi Islam lainnya dalam keilmuan komunikasi yang sampai saat ini belum banyak digali dan diteliti. Misalnya, terdapat banyak ayat dalam AlQur'an yang memuat kerangka teori dan sumber inspirasi bagi perkembangan keilmuan komunikasi seperti halnya komunikasi persuasi/profetik.

Dijelaskan dalam QS. Ali Imran: 110 bahwa Allah telah menyerukan manusia utuk berbuat baik dan menjauhi yang munkar agar dapat mendekatkan diri dengan Allah SWT;

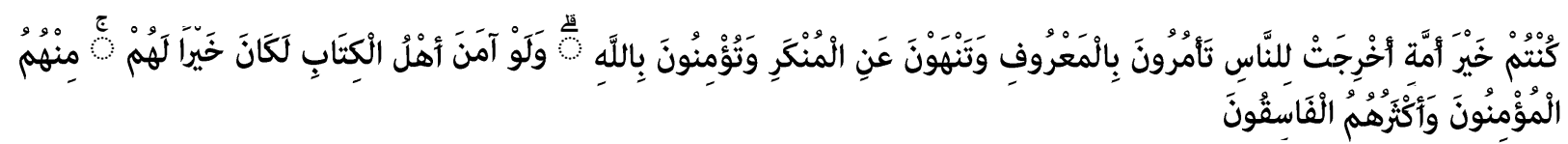

Artinya: "Kamu adalah umat yang terbaik yang dilahirkan untuk manusia, menyuruh kepada yang ma'ruf, dan mencegah dari yang munkar, dan beriman kepada Allah. Sekiranya Ahli Kitab beriman, tentulah itu lebih baik bagi mereka, di antara mereka ada yang beriman, dan kebanyakan mereka adalah orang-orang yang fasik".

Kandungan nilai dari ayat tersebut syarat dengan makna sosial, kewajiban untuk memberikan seruan kepada kebaikan dan mencegah pada perbuatan yang munkar yang berarti menginginkan perubahan tingkah laku manusia yang lebih baik. Dengan demikian, sudah jelas bawa Islam memuat sejumlah kerangka teori transenden melalui teks (nash) bagi pengembangan ilmu komunikasi.

Menerapkan nilai-nilai profetik diperlukan pesan yang dapat menarik pehatian santri serta mudah dipahami sehingga dapat mengubah tingkah laku yang diinginkan sesuai pesan yang disampaikan. Tugas-tugas profetik inilah yang harus dilakukan oleh orang-orang terpilih untuk melakukan humanisasi dan liberasi dalam kerangka transedensi. Oleh karena itu diperlukan umat Islam yang mengerti dalam agama serta ilmu sehingga menggerakkan sebuah kesadaran transformasi sosial. Menggerakkan kesadaran yang paling efektif adalah melalui media massa atau setidaknya melalui media pendidikan. Pendidikan dalam agama Islam, secara tidak langsung berupaya untuk mengajarkan dan menanamkan pendidikan karakter atau akhlak mulia sebagaimana cita-cita Islam yang berdasarkan pada nilai-nilai Al-Qur'an. Pendidikan karakter yang bernilai profetik biasanya dipelajari lebih dalam di pondok pesantren dengan menanamkan akhlak yang baik kepada para santri.

Pondok Pesantren Al-Ittifaqiah (PPI) merupakan salah satu dari 20 pesantren yang berpengaruh di Indonesia. Berdasarkan buku yang di tulis oleh Olman Dahuri dan Nida' Fadlan 
melalui hasil survei lembaga Emir Cakrawala Islam terhadap 27.230 pesantren di Indonesia. Kehadiran Pondok Pesantren Al-Ittifaqiah di Indralaya Kabupaten Ogan Ilir Sumatera Selatan yang berada dibawah naungan Yayasan Islam Al-Ittifaqiah (YALQI) sebagai tempat mendalami agama dan menjadi lembaga pendidikan bagi masyarakat sangat membantu dalam menyiarkan agama Islam.

Disamping menyediakan wadah sebagai sosialisasi, pesantren juga merupakan tempat mengaji dan mempelajari kitab-kitab, dan menjadi tempat intentifikasi peribadatan yang biasa dilakukan. Dalam menarik minat masyarat untuk menuntut ilmu agama santri di pesantren ini banyak mengukir prestasi dibidang Musabaqah Tilawatil Quran (MTQ) internasional di Malaysia pada tahun 1997 dan 2006, juara Musabaqah Tilawatil Quran (MTQ) internasional di Saudi Arabia 2001, juara STQ/MTQ Nasional, juara pidato Bahasa Arab pekan olaraga nasional dan juara pada beragam event nasional lainnya. Karena prestasi-prestasi tersebut santri PPI tahun 1999 mendapat pengakuan dari Departemen Agama sebagai pondok pesantren unggulan (Warfiah, 2015).

Pondok pesantren ini juga menggunakan sistem yang memadukan pembelajaran perorangan dan sistem pengajian bersama seperti membangun beberapa lembaga seperti LEMTATITIQI (Lembaga Tahfizh Tilawah dan Ilmu Al-Qur'an Al-Ittifaqiah) dalam membina santri untuk menghafal Al-Quran. PPI menjadikan Al-Qur'an sebagai ciri khas dan program unggulan, baik dari kemampuan membaca, menghafal, seni baca, ilmu-ilmunya, maupun kemampuan memahami dan praktek melaksanakan ajaran-ajaran Al-Qur'an (Profil PP alIttifaqiah, 2018). Dengan adanya program ini dimaksudkan agar tertanamnya nilai-nilai profetik dalam diri para penghafal Al-Qur'an.

Pelaksanaan nilai-nilai profetik di Pondok Pesantren Al-Ittifaqiah salah satunya dalam proses mengajak santri untuk menghafal Al-Qur'an. Nilai-nilai tersebut kemudian diimplementasikan oleh para guru sehingga para santri berminat untuk menghafal Al-Qur'an tanpa adanya rasa paksaan tetapi karena keinginan sendiri. Pesan yang disampaikan oleh guru dapat mempengaruhi pola pikir dan mengubah tingkah laku para santri sesuai dengan apa yang disampaikan. Penyampaian pesan yang dilakukan oleh para guru dapat berupa nasihat-nasihat ataupun motivasi yang membangun sehingga dapat mendorong keinginan santri untuk menghafal Al-Qur'an. Namun demikian, dalam mengajak santri untuk menghafal Al-Qur'an ini juga tentunya terdapat hambatan-hambatan di dalamnya. Oleh karena itu diperlukan keseriusan dan kelembutan hati dalam mengajak santri untuk menghafal Al-Qur'an sehingga terciptalah komunikasi yang bernilai humanis, liberasi dan transedensi di lingkungan pondok pesantren.

Santri yang belajar di Pondok Pesantren Al-Ittifaqiah terbagi dalam dua kategori, yaitu santri mukim (menetap) dan santri non mukim (tidak menetap). Santri mukim merupakan santri yang bertempat tinggal di dalam pondok pesantren, dan mengikuti segala aturan yang ada selama 24 jam. Sedangkan santri non mukim adalah santri yang hanya mengikuti kegiatan harian dan tidak bertempat tinggal di pondok pesantren. Oleh karena itu terdapat perbedaan waktu belajar di antara keduanya. 


\section{METODE PENELITIAN}

Penelitian ini akan dilaksanakan di Pondok Pesantren Al-Ittifaqiah yang berada di Jl. Lintas Timur KM. 36 Desa Indralaya Mulya Kec. Indralaya Kab. Ogan Ilir Prov. Sumatera Selatan Indonesia. Metode yang digunakan dalam penelitian ini menggunakan metode pendekatan kualitatif. Peneliti menggunakan pendekatan kualitatif berdasarkan beberapa pertimbangan yang pertama, karena judul penelitian ini hanya mengandung satu variabel. Kedua, dari rumusan masalah yang diangkat dalam penelitian ini menuntun peneliti untuk terjun langsung ke lapangan. Ketiga, metode kualitatif lebih peka dan dapat menyesuaikan diri dengan banyak penajaman pengaruh bersama terhadap pola-pola nilai yang dihadapi. Berlandaskan dari latar belakang diatas, peneliti akan mengambil subjek penelitiannya adalah santri non mukim serta para guru tahfizh di Pondok Pesantren Al-Ittifaqiah Indralaya.

Adapun kriteria santri disini adalah santri yang telah mengikuti kegiatan minimal satu tahun. Penelitian ini berfokus pada aspek profetik dimana nilai-nilai humanisasi, liberasi dan transedensi diterapkan di lingkungan Pondok Pesantren Al-Ittifaqiah. Adapun objek penelitian kajian yang telah difokuskan oleh peneliti berupa proses komunikasi yang digunakan sehari-hari dalam membangun nilai profetik. Berdasarkan subjek dan objek yang akan diteliti, maka ada dua jenis data yang dikumpulkan dalam penelitian ini, yaitu: data primer, yang diperoleh secara langsung dilapangan dari subjek penelitian dan data sekunder, data yang digunakan peneliti untuk membantu dan mendukung data primer. Peneliti menggunakan metode observasi dan dokumentasi sebagai pelengkap dalam mengumpulkan data yang otentik. Data yang diperoleh akan dianalisis melalui reduksi data, penyajian data, dan penarikan kesimpulan.

\section{HASIL DAN PEMBAHASAN}

\section{Pelaksanaan Komunikasi Profetik dalam Mengajak Santri Non Mukim Menghafal Al- Qur'an}

Komunikasi profetik menempatkan komunikasi Rasulullah SAW ke dalam konteks masa lalu yang kemudian diserap nilainya pada konteks saat ini dengan harapan agar komunikasi profetik mampu muncul sebagai konsep alternatif yang memberikan pencerahan dan kemerdekaan yang selama ini justru memperbudak manusia (Syahputra, 2007). Dengan demikian pelaksanaan nilai-nilai profetik dalam kehidupan sehari-hari dapat menciptakan generasi masa depan yang berakhlak dan beretika. Adapun pengertian dari ketiga nilai-nilai profetik tesebut dan hubungannya dengan ajakan dalam menghafal Al-Qur'an adalah :

\section{A. Humanisasi}

Humanisasi dalam bentuk mengajak seseorang untuk menghafal Al-Qur'an merupakan salah satu dari ajakan kebaikan yang dapat mendekatkan diri kepada Allah SWT. Dengan mempelajari, menghafal dan memahami nilai-nilai Al-Qur'an akan menjauhkan diri dari hal-hal yang tidak diinginkan. Menghafal Al-Qur'an juga dapat menciptakan generasi yang penuh etika. 
Adapun pelaksanaan nilai-nilai profetik melalui ajakan dalam menghafal Al-Qur'an yang dilakukan di Pondok Pesantren Al-Ittifaqiah (PPI) kepada santri non mukim, antara lain :

a. Melalui komunikasi yang baik

Komunikasi merupakan alat terbaik dalam membentuk jati diri dan pola pikir seseorang. Oleh karena itu, pentingnya memahami santri ketika akan menyampaikan pesan ataupun nasihat-nasihat lainnya sehingga dapat berdampak positif bagi para santri. Pondok Pesantren Al-Ittifaqiah (PPI) mengajak santri untuk menghafal Al-Qur'an melalui komunikasi yang baik sehingga dapat menggerakkan hati para santri agar berkeinginan untuk mempelajari dan menghafal Al-Qur'an. Ketika seorang guru menyampaikan pesan yang sarat akan makna, mudah dipahami serta sesuai dengan keadaan santrinya maka pesan akan diterima dengan baik oleh para santri.

Pesan yang disampaikan oleh seorang guru bukan hanya memberikan efek untuk jangka pendek, tetapi juga efek jangka panjang yang akan dirasakan selama di dunia maupun di akhirat kelak. Hal tersebut selalu disampaikan oleh para guru di PPI ketika dalam kelas ataupun ketika sedang melaksanakan apel pagi, sehingga terbetuklah motivasi dan pikiran yang positif dari para santri dalam menghafal Al-Qur'an.

b. Memberikan motivasi

Guru berusaha mendorong dan memotivasi santri agar mereka meyakini bahwasannya hasil dari belajar dan menghafal Al-Qur'an bukan hanya sekedar dapat dirasakan pada saat di dunia, tetapi juga akan bermanfaat untuk bekal di akhirat kelak. Salah satu motivasi yang diberikan oleh para guru kepada santrinya yaitu melalui penjelasan tentang keutamaan, manfaat dan keberkahan menghafal Al-Qur'an. Dengan demikian, para santri akan terus berusaha untuk mencapai tujuan yang diinginkan melalui menghafal Al-Qur'an dan mengamalkan Al-Qur'an sehingga terbentuklah generasi yang berakhlak sesuai dengan ajaran Al-Qur'an.

Motivasi-motivasi dalam hal yang bersifat duniawi pun juga sesekali disampaikan untuk mendorong santri dalam menghafal. Semua guru menyampaikan bahwasannya dengan menghafal Al-Qur'an akan memudahkan santri dalam melanjutkan ke sekolah yang diimpikan, karena banyaknya beasiswa yang diperuntukkan bagi para penghafal Al-Qur'an baik dari dalam negeri maupun luar negeri yang disediakan oleh pemerintah ataupun swasta sehingga tidak ada kata terlambat ataupun terkekang karena menghabiskan waktu untuk menghafal Al-Qur'an.

Banyak alumni PPI yang mendapatkan beasiswa dan melanjutkan ke Universitas Luar Negeri, misalnya; Universitas Internasional Afrika Sudan, Universitas Al-Ahqaf Yaman, Universitas Al-Azhar Kairo Mesir, Universitas Kebangsaan Malaysia, Universitas Arizona Amerika Serikat, Universitas Sidney Australia dan lainya. Selain itu, alumni PPI juga banyak yang mendapat beasiswa di perguruan tinggi ternama di dalam negeri seperti, UIN Syarif Hidayatullah Jakarta, UIN Sunan Kalijaga Yogyakarta, UIN Raden Fatah Palembang, Universitas Sriwijaya Indralaya, IIQ Jakarta, PTIQ, LIPIA Jakarta, Sekolah Tinggi Ekonomi Islam Taskia Jakarta dan lain-lain.

Jadi, manfaat dari menghafal Al-Qur'an bukan hanya hal yang bersifat spiritual, tetapi juga manfaat dalam berahlak dan beretika, manfaat keilmuan serta manfaat intelektual. Oleh karena itu, 
melanjutkan pendidikan tinggi ke Luar Negeri ataupun dalam Negeri bagi santri penghafal AlQur'an merupkan salah satu hasil dari manfaat menghafal Al-Qur'an.

c. Memberikan sosialisasi

Selain memberikan motivasi, pondok pesantren juga memberikan sosialisasi saat upacara dan apel pagi berkaitan dengan santri-santri yang berprestasi. Sosisalisasi diharapkan dapat meningkatkan minat para santri dalam berprestasi dan dapat menambah kecintaan dalam mempelajari Al-Qur'an. Pondok pesantren memberikan penghargaan bagi para santri yang berprestasi dan telah memiliki hafalan minimal 10 juz. Jadi, pondok pesantren bukan hanya memberikan dorongan yang bersifat immaterial, tetapi juga memberikan hal yang bersifat material untuk meningkatkan prestasi para santri.

Adapun salah satu santri non mukim berprestasi dalam bidang hafalan Al-Qur'an yang mendapat penghargaan yaitu, Lian Tarina. Santri tersebut berhasil mendapatkan juara 3 MTQ tingkat Provinsi Sumatera Selatan kategori Hifzhil 5 juz dan Tilawah yang diselenggarakan di kabupaten Ogan Ilir tahun 2018. Lian Tarina juga berhasil meraih jura 1 STQH tingkat Provinsi Sumatera Selatan pada tahun 2019. Dengan demikian, tidak ada hambatan bagi santri non mukim untuk berprestasi walaupun tidak tinggal di lingkungan pondok pesantren.

Pondok Pesantren Al-Ittifaqiah (PPI) juga mengadakan sosialisasi melalui kegiatan sima 'an rutinan bagi seluruh santri tahfizh di PPI. Kegiatan sima'an bertujuan untuk melancarkan hafalan para santri serta mengajak santri lain untuk menghafal ketika mendengar lantunan-lantunan ayat Al-Qur'an yang dibacakan oleh para santri tahfizh. Melalui sima'an juga dapat berdampak baik bagi yang membaca maupun mendengarkannya dalam membentuk karakter seseorang. Jadi, sosialisasi yang diadakan bukan hanya memberikan penghargaan, tetapi juga melalui sima'an rutinan tersebut. Sima'an merupakan kegiatan yang sangat penting untuk santri yang menghafal Al-Qur'an serta. Selain itu juga, sima'an bertujuan untuk menarik santri lainnya untuk ikut menghafal. Bukan hanya diikuti oleh santri mukim, sima'an juga diikuti oleh santri non makim.

Lingkungan PPI berusaha membentuk generasi qur'ani di masa depan dengan memberikan contoh dan kegiatan-kegiatan yang baik di lingkungan pondok pesantren. Misalnya sebelum apel pagi, seluruh santri diwajbkan untuk melaksanakan shalat dhuha terlebih dahulu berjama'ah. Maka demikian para santri diharapkan akan terbiasa dengan aktivitas rutinan tersebut sebelum melakukan kegiatan apapun di pagi hari. Kemudian PPI juga selalu mengadakan simaa'an setiap malam Jum'at. Walaupun sifatnya tidak wajib, tapi para santri non mukim kebanyakan ikut hadir dalam kegiatan tersebut dikarenakan kebiasaan mereka mendengarkan lantunan ayat Al-Qur'an di pondok pesantren membuat rasa ketertarikan tersendiri dari kegiatan tersebut. Hal baik yang dilakukan dengan rutin tersebut kemudian dapat menjadi kegiatan yang biasa dilakukan dalam kehidupan sehari-hari sehingga terbentuklah generasi-generasi qur'ani yang berahlak dan beretika di masa depan.

Pembentukan karakter membutuhkan proses yang sangat panjang hingga akhirnya dapat berahlak seperti Rasulullah SAW. Membentuk generasi yang berahlak mulia harus dilakukan sedini mungkin agar tidak ada penyesalan di kemudian hari. Begitupun juga dengan menghafal Al- 
Qur'an. Ahsin Sakho Muhammad dalam bukunya mengatakan, “Anak-anak dan murid-murid yang kau ajari Al-Qur'an dan kau jadikan mereka penghafal Al-Qur'an, mereka belum tahu bahwa mereka telah diberikan bongkahan-bongkahan emas yang begitu mahal. Mereka tidak tahu apa guna bongkahan-bongkasan emas itu?. Kelak jika mereka sudah dewasa dan berilmu, mereka akan tahu bahwa semua yang mereka dapatkan adalah kekayaan yang tak ternilai harganya" (Muhammad, 2017).

Berdasarkan pesan di atas, menghafal Al-Qur'an merupakan bentuk usaha dalam mendidik generasi-generasi yang berilmu, beriman, berahlak dan beretika. Menghafal Al-Qur'an akan terus bermanfaat dan dirasakan bukan hanya di dunia tetapi juga di akhirat. Al-Qur'an merupakan wahyu suci dari Allah SWT sehingga hanya orang-orang tertentu yang dapat teus ber istiqamah dalam menghafal Al-Qur'an. Namun demikian, semua orang memiliki kewajiban dalam mengajak seseorang menghafal Al-Qur'an karena menghafal Al-Qur'an merupakan salah satu bentuk dari mengajak kebaikan.

Al-Qur'an adalah amanah yang diberikan oleh Allah, maka hanya orang-orang yang benarbenar memiliki keinginan dan tekad kuat yang dapat menjalankan amanah tersebut. Oleh karena itu, menghafal Al-Qur'an merupakan pilihan setiap orang yang mampu mengemban amanah dari Allah SWT dan tidak bisa dipaksakan. Namun ketika seseorang telah memilih untuk menghafal Al-Qur'an maka mau tidak mau harus mematuhi setiap aturan-aturan dan target yang telah ditetapkan. Para guru selalu mengingatkan santri untuk menjauhi segala bentuk maksiat seperti halnya pacaran, walapun hal tersebut memang sudah di larang oleh Allah SWT kepada siapapun.

Jika sudah demikian, langkah terbaik adalah merajut kembali niat awal dalam menghafal Al-Qur'an dan mengulangnya sesering mungkin agar tidak mudah lepas. Rasulullah SAW bersabda:

"Perumpamaan orang yang menghafal Al-Qur'an itu tidak lain seperti orang yang memiliki unta yang diikat kakinya, jika ia selalu memperhatikan untanya, ia akan bisa menahan unta tersebut, tetapi jika tidak memperhatikannya, maka untanya akan lepas pergi”.

Berdasarkan hadist di atas, Rasulullah SAW sangat memaklumi bahwa penghafal AlQur'an memang mudah lupa dengan hafalannya. Oleh karena itu diperlukan target pencapaian agar santri tidak bermalas-malasan dalam menghafal.

Target ini diharapakan agar santri tidak bermalas-malasan dalam menghafal dan muroja'ah sehingga hafalan Al-Qur'annya dapat terselesaikan dengan cepat dan lancar. Ketika para santri pulang ke rumah, guru tetap memberikan tugas menambah hafalan untuk kemudian disetorkan keesokan harinya di pondok pesantren. Dengan demikian, walaupun santri sudah tidak berada di lingkungan pondok pesantren, meraka tetap mengisi kesibukan dengan menghafal di rumah sehingga terbiasa dengan kesibukan yang bersifat positif. Hal tersebut juga dapat menjauhkan para santri dari pengaruh teknologi yang dapat mempengaruhi tingkah laku yang tidak diinginkan dan dapat melalaikan waktu dengan kesibukan yang tidak bermanfaat.

Tugas menghafal di rumah ini juga diharapkan dapat mengajak keluarga di rumah untuk dekat dengan Al-Qur'an melalui rutinitas santri tersebut ketika berada di rumah. Sehingga 
keberkahan dan manfaat menghafal Al-Qur'an dapat dirasakan bukan hanya untuk diri sendiri, tetapi juga orang lain. Mengajak orang lain untuk belajar dan menghafal Al-Qur'an merupakan usaha untuk menciptakan pribadi-pribadi yang memiliki dimensi pembebasan dari segala bentuk penindasan, orientasi pada materialisme dan hedonisme. Mencetak generasi penghafal Al-Qur'an juga merupakan usaha untuk memposisikan diri sebagai pemain perubahan sesuai dengan anjuran Allah SWT melalui ajaran-ajaran Islam yang disampaikan oleh Rasulullah SAW.

Tugas-tugas profetik harus dilakukakan oleh orang-orang terpilih untuk melakukan humanisasi dan liberasi dalam kerangka transedensi. Amar ma'ruf yang berarti humanisasi dan emansipasi, sedangkan nahi munkar adalah upaya untuk liberasi. Kedua tugas tersebut berada dalam kerangka keimanan sehingga tidak bisa dipisahkan dari transedensi.

Makna transedensi dalam mengajak satri non mukim untuk menghafal Al-Qur'an merupakan bentuk pendekatan diri dengan Allah SWT melalui ajakan untuk berbuat kebaikan dan menjauhkan diri dari hal yang tidak baik denga maksud agar senantiasa selalu dekat dengan Allah SWT. Dengan demikian jika nilai-nilai profetik ini dihubungkan dengan proses ajakan PPI kepada santri non mukim dalam menghafal Al-Qur'an maka cita-cita untuk humanisasi, liberasi dan transedensi telah terealisasikan di PPI.

Menghafal Al-Qur'an merupakan bentuk hidayah yang diberikan Allah SWT untuk orangorang yang bertakwa. Malalui Al-Qur'an, manusia mampu menemukan kebenaran untuk memperoleh keselamatan di dunia dan di akhirat. Seorang yang menghafal Al-Qur'an seharusnya menjadi generasi unggul dari generasi ke generasi. Jika tidak tercapai, maka orang tersebut belum melaksanakan ajaran Al-Qur'an dengan sebenar-benarnya. Namun demikian, komunikasi yang baik juga diperlukan dalam menyampaikan isi kandungan dari Al-Qur'an sehingga dapat dipahami dengan baik dan dapat mencipkan generasi yang berahklak dan beretika.

Pondok Pesantren Al-Ittifaqiah (PPI) dalam mengajak santri non mukim menghafal AlQur'an merupakan bagian dari usaha membentuk generasi-generasi yang beriman, berahlak dan beretika. Melihat kondisi lingkungan luar yang bebas membuat para guru terus berusaha menanamkan nilai-nilai Al-Qur'an pada diri santri saat berada di lingkungan pondok pesantren. Melalui komunikasi yang baik dan motivasi dari para guru sangat membantu dalam proses menghafal para santri. Para guru di PPI selalu memberikan pesan-pesan ataupun nasihat yang baik bagi santrinya. Dengan demikian, dapat dilihat betapa pentingnya komunikasi yang baik antara seorang guru dan santri dalam mengajak kebaikan.

Menghafal Al-Qur'an bukan hanya bentuk dari amar ma'ruf nahi munkar tetapi juga inti dari tu'minu billah (transedensi). Dengan menghafal Al-Qur'an, seseorang akan selalu dekat dengan Allah SWT, ingat Allah SWT, sehingga senantiasa untuk melakukan amar ma'ruf nahi munkar sebagaimana yang diperintahkan Allah SWT dalam QS. Ali 'Imran: 110.

Aktivitas mengajak dalam pandangan komunikasi diistilahkan sebagai "persuasi". Gerald R. Miller mengatakan bahwa persuasi merupakan situasi yang dibuat untuk mengubah perilaku melalui transaksi (pesan) simbolik yang bersifat tidak memaksa (secara tidak langsung) dengan alasan yang masuk akal dan melibatkan emosi terhadap orang-orang yang akan dipengaruhi 
tersebut (Chafee, 1987). Setidaknya ada keterlibatan antara dua pihak dalam proses persuasi yaitu pihak yang mengajak dan pihak yang di ajak.

Proses persuasi ini jika dianalisis menggunakan teori penguatan (reinforcement theory) maka akan ada hubungan yang terjalin antara teori penguatan dan profetik. Teori ini mengatakan bahwasannya perubahan sikap itu merupakan hasil dari perubahan opini (pendapat) komunikan melalui penguatan pesan. Penguatan pesan tersebut dirancang agar seseorang mengubah tingkah lakunya dan mengurangi tingkah laku yang tidak diinginkan. Hanya saja teori ini tidak menjadikan perubahan sikap itu sebagai bentuk usaha untuk menuju nilai yang transenden. Sedangkan profetik, menjadikan transenden sebagai tujuan utama dalam membentuk tingkah laku seseorang. Profetik mengubah tingkah laku seseorang sesuai dengan yang diajarkan oleh Rasulullah SAW melalui penjelasan dari Al-Qur'an dan Hadist.

Saat mengajak santri non mukim menghafal Al-Qur'an, para guru membuat pesan yang dapat menarik perhatian, mudah dipahami, serta sesuai dengan kondisi latar belakang dan lingkungan tempat tinggal santri. Hal tersebut merupakan bentuk usaha agar tertanamnya nilai humanisasi, liberasi dan transedensi sehingga tercipta generasi yang berahlak dan beretika sesuai dengan yang diajarkan oleh Rasulullah SAW. Berdasarkan pengertian nilai-nilai profetik yang telah dijelaskan di atas serta hubungannya dengan ajakan dalam menghafal Al-Qur'an, maka terdapat nilai-nilai profetik dalam proses ajakan kepada santri non mukim untuk menghafal AlQur'an.

\section{Hambatan dalam Mengajak Santri Non Mukim untuk Menghafal Al-Qur'an}

Adapun hambatan-hambatan yang didapatkan saat mengajak santri non mukim untuk menghafal Al-Qur'an adalah :

a. Sulitnya berkomunikasi langsung dengan santri non mukim

Komunikasi merupakan pondasi utama bagi setiap orang dalam menjalin kekeluargaan. Namun ketika komunikasi sudah tidak berjalan efektif, maka akan ada misscommunication diantara keduanya. Hal tersebut terjadi pada guru dan santri non mukim yang menghafal Al-Qur'an di Pondok Pesantren Al-Ittifaqiah. Lokasi tempat tinggal santri non mukim yang berada di luar lingkungan pondok menjadi batasan bagi para guru untuk berkomunikasi.

Misalnya ketika ada santri non mukim yang kurang aktif di kelas atau belum mencapai target, maka diperlukan komunikasi mendalam diantara keduanya agar guru mengetahui apa saja hambatan-hambatan santri tersebut dalam menghafal. Namun karena adanya jarak dan hanya bertemu saat jam belajar, maka pesan yang akan disampaikan oleh guru tersebut hanya melalui santri lainnya sebagai perantara dalam menyampaikan pesan. Terkadang saat guru memanggil santri tersebut pada jam pulang sekolah agar tidak mengganggu jam belajar sekolah, namun sangat disayangkan santri tersebut malah sudah pulang duluan sehingga pesan yang akan disampaikan pun tidak terlaksana.

Kondisi ini membuat para guru kesulitan dalam mengenal santri baik secara pedekatan di dalam kelas ataupun di lingkungan sekitar pesantren. Guru yang semestinya mengenal dan 
memahami para santri agar lebih timbul rasa peduli dan mengenal tetapi terhambat dalam hal ini. Maka demikian, proses komunikasi pun tidak berjalan dengan efektif.

b. Lingkungan tempat tinggal yang kurang mendukung

Lingkungan juga merupakan faktor penting dalam membentuk pribadi dan prilaku seseorang, begitupun dengan penghafal Al-Qur'an. Jika seorang penghafal Al-Qur'an tinggal di lingkungan umum, dikhawatirkan dapat melalaikan orang tersebut untuk menjaga hafalannya. Mengingat sifat Al-Qur'an yang mudah lepas maka dalam keadan apapun harus sering di-deres hafalannya. Jika santri yang menghafal Al-Qur'an berada di rumah maka akan banyak sekali godaan yang dapat melalaikan waktu menghafal seperti, membuang waktu untuk menonton TV, bermain gadget, mengobrol, dan lainnya.

Seorang yang menghafal Al-Qur'an seharusnya tinggal di lingkungan orang-orang yang menghafal juga agar terciptanya suasanya yang religius. Jika para penghafal Al-Qur'an berkumpul, maka dapat dipastikan kegiatan yang dilakukan menciptakan suasana yang religius. Hal ini sesuai dengan sabda Nabi SAW bahwa ketika ada sekumpulan orang membaca Al-Qur'an, maka akan tercipta suasana tenang, rahmat Allah SWT akan menyertai mereka, malaikat pun mengelilingi mereka (Muhammad, 2018). Setidaknya dengan berkumpul di lingkungan orang-orang yang menghafal Al-Qur'an ada yang mengingatkan ketika dalam keadaan malas untuk menghafal ataupun muroja'ah.

Lingkungan merupakan faktor utama dalam membentuk generasi yang berahlak. Oleh karena itu, selain guru yang berada di pondok pesantren, orang tua santri juga memiliki peran penting dalam mendukung santri untuk menghafal Al-Qur'an saat berada di rumah. Orang tua harus senantiasa mengontrol kegiatan santri tersebut agar senantiasa berada dekat dengan Al-Qur'an.

c. Kurang efektifnya waktu menghafal

Lingkungan dan waktu merupakan hal yang saling berkaitan. Ketika seorang santri yang menghafal Al-Qur'an tinggal di lingkungan yang bebas, maka waktu-waktu yang seharusnya digunakan untuk mengaji malah digunakan untuk melakukan kegiatan-kegiatan lain seperti malas-malasan di rumah, menonton televisi, bermain gadget, dan lainnya.

Waktu menghafal di lingkungan luar berbeda dengan lingkungan pesantren. Di dalam pesantren, terdapat waktu khusus bagi santri yang menghafal Al-Qur'an untuk menambah maupun megulang hafalannya. Misalnya $b a$ ' $d a$ shalat 'Isya, santri yang tinggal di asrama diwajibkan untuk mengikuti kegiatan belajar bersama/menghafal bersama di mushalla. Dengan demikian, dapat membantu proses menghafal para santri sehingga lebih efektif dalam memanfaatkan waktu.

Hal tersebut merupakan kebijakan dari pondok pesantren agar para santri dapat memanfaatkan waktu malam hari untuk tetap belajar. Karena lingkungan pesantren adalah lingkungan dengan suasana religius, maka santri-santri yang awalnya bermalas-malasan pun akan termotivasi dengan teman-teman lain yang sedang menghafal. Berbeda dengan lingkungan luar yang sudah berbaur dengan segala jenis teknologi yang dapat melalaikan waktu.

d. Terlalu banyak alasan saat akan menyetorkan hafalan 
Alasan sebenarnya bukan masalah. Hanya saja kebanyakan orang menyalah gunakan alasan tersebut. Berdasarkan hasil wawancara terhadap beberapa guru tahfizh, alasan yang sering disampaikan santri ketika tidak mengikuti kelas tahfizh yaitu; ban motor pecah, macet dan takut tertinggal angkot (angkutan kota) kalau pulang terlalu sore.

Hambatan-hambatan yang telah dijelaskan di atas merupakan hambatan yang sering terjadi di PPI. Oleh karena itu, dalam mengatasi hambatan-hambatan tersebut diperlukan komunikasi mendalam antara guru dan santri yang dilandasi spiritual sehingga dapat menjadi perisai dasar akan semua kebaikan. ketika menyampaikan pesan, seorang guru harus memperhatiakan terlebih dahulu pesan yang akan disampaikan. Sebelum menyampaikan pesan, pastikan agar pesan tersebut sesuai dengan tingkah laku dan kondisi santri, agar dapat tersampaikan dengan baik. Jika demikian, kelangsungan proses humanisasi, liberasi dan transedensi dapat dilaksanakan dalam mengajak santri non mukim untuk menghafal Al-Qur'an.

Salah satu cara berkomunikasi yang dapat diterapkan saat menasihati orang yaitu dengan mengajukan pertanyaan-pertanyaan sehingga dapat merangsang kecerdasan komunikasi, emosi, dan spiritual dan menggali kemampuan atau potensi diri mereka sehingga nasihat atau masukanmasukan yang diberikan kepada meraka dapat merasuk ke dalam jiwa dan melekat ke dalam pikiran (Pambayun, 2012).

Al-Qur'an yang sarat dengan pesan-pesan yang dapat menggerakkan hati manusia menjadi pribadi yang berakhlak mulia dapat dijadikan sebagai alat dalam menyampaikan nasihat sekaligus motivasi untuk santri. Memberikan nasihat dengan kata-kata yang baik akan menuntun dan mengarahkan ke jalan kebajikan. Islam pun telah menetapkan interaksi dan komunikasi pada sesama hamba Allah SWT dengan meletakkan kaidah-kaidah dasarnya dalam Al-Qur'an.

\section{KESIMPULAN}

Komunikasi profetik yang dilaksanakan dalam mengajak santri non mukim menghafal Al-Qur'an bahwasannya, sebelum menyampaikan pesan, seorang guru memperhatiakan tingkah laku, kondisi dan latar belakang santri sehingga dapat dipastikan pesan tersebut dapat diterima dengan baik oleh para santri. Guru memberikan motivasi yang dapat meningkatkan semangat menghafal para santri. Motivasi disampaikan para guru mengenai manfaat, keutamaan dan keberkahan dalam menghafal Al-Qur'an di dunia maupun di akhirat serta memberikan nasihat-nasihat baik melalui 'ibrah (pelajaran) yang telah terjadi. Selain itu, sosialisasi juga diadakan oleh pondok pesantren dengan memberikan penghargaan bagi santri-santri yang berprestasi saat upacara/apel pagi. Sehingga para santri ikut termotivasi dengan adanya apresiasi dari pondok tersebut.

Adapun hambatan yang didapatkan saat mengajak santri non mukim dalam menghafal AlQur'an yaitu, sulitnya berkomunikasi langsung dengan santri non mukim karena pengaruh jarak yang tidak memungkinkan. Kemudian lingkungan tempat tinggal yang tidak mendukung juga merupakan hambatan yang dirasakan oleh para guru maupun santri non mukim itu sendiri. 


\section{DAFTAR PUSTAKA}

Dahuri, Olman, Fadlan, Nida'. (2015). Pesantren-Pesantren Berpengaruh di Indonesia, Jakarta: Erlangga.

Dhofier, Zamakhsyari. (1982). Tradisi Pesantren "Studi Tentang Pandangan Kyai”, Jakarta: LP3ES.

Kriyantono, Rachmat. (2006). Teknik Praktis Riset Komunikasi, Jakarta: Kencana Prenada Media Group.

Kuntowijoyo. (2005). Islam Sebagai Ilmu, Efistemologi, Metodologi, dan Etika, Bandung: Teraju Mizan.

Liliweri, Alo. (2011). Komunikasi Serba Ada Serba Makna, Jakarta: Kencana.

Madjid, Nurchalish. (1997). Bilik-Bilik Pesantren "Sebuah Potret Perjalanan", Jakarta: Paramadina.

Moleong, Lexy J. (2014). Metode Penelitian Kualitatif, Bandung: Rosdakarya.

Muhammad, Ahsin Sakho. (2018). Menghafal Al-Qur'an "Manfaat, Keutamaan, Keberkahan, dan Metode Praktisnya", Jakarta: PT. Qaf Media Kreativa.

Pambayun, Ellys Lestari. (2012). Communication Quotient "Kecerdasan Komunikasi dalam Pendekatan Emosional dan Spiritual", Bandung: Rosdakarya.

Penyusun. (2018). Profil Pondok Pesantren Al-Ittifaqiah Indralaya Ogan Ilir Sumatera Selatan Indonesia, Indralaya: PPI.

Sugiono. (2014). Metode Penelitian Kombinasi, Bandung: Alfabeta.

Syahputra, Iswandi. (2007). Komunikasi Profetik “Konsep dan Pendekatan”, Bandung: Sembiosa. . (2017). Paradigma Komunikasi Profetik, Bandung: Sembiosa.

Vardiansyah, Dani. (2006). Filsafat Ilmu Komunikasi Suatu Pengantar, Jakarta: Indeks. 